5-2-1995

\title{
Electrochemical Carbonylation of Organoiron Methyl Complex: A Study of Reaction Intermediates
}

\author{
C. Amatore \\ Ecole Normale Superieure
}

Mekki Bayachou

Cleveland State University, M.BAYACHOU@csuohio.edu

J. N. Verpeaux

Ecole Normale Superieure

L. Pospisil

Institute of Physical Chemistry

J. Fiedler

Institute of Physical Chemistry

Follow this and additional works at: https://engagedscholarship.csuohio.edu/scichem_facpub

Part of the Chemistry Commons

How does access to this work benefit you? Let us know!

\section{Recommended Citation}

Amatore, C.; Bayachou, Mekki; Verpeaux, J. N.; Pospisil, L.; and Fiedler, J., "Electrochemical Carbonylation of Organoiron Methyl Complex: A Study of Reaction Intermediates" (1995). Chemistry Faculty Publications. 310.

https://engagedscholarship.csuohio.edu/scichem_facpub/310

This Article is brought to you for free and open access by the Chemistry Department at EngagedScholarship@CSU. It has been accepted for inclusion in Chemistry Faculty Publications by an authorized administrator of EngagedScholarship@CSU. For more information, please contact library.es@csuohio.edu. 


\title{
Electrochemical carbonylation of organoiron methyl complex: a study of reaction intermediates
}

\author{
C. Amatore , M. Bayachou J.-N. Verpeaux , L. Pospíšil J. Fiedler
}

\begin{abstract}
The one-electron reduction of $\mathrm{CpFe}(\mathrm{CO})_{2} \mathrm{CH}_{3}$ has been investigated by voltammetry and Fourier transform IR spectroelectrochemistry. The reduction initiates the insertion of $\mathrm{CO}$ ligand in the $\mathrm{Fe}-\mathrm{CH}_{3}$ bond. The dissociation of a $\mathrm{CO}$ group proceeds in a parallel reaction. Reaction intermediates, the acyl derivative and released $\mathrm{CO}$, form the radical anion of a complex $\left.\mathrm{CpFe}_{2} \mathrm{CO}\right)_{2}\left(\mathrm{COCH}_{3}\right)$ which is able to reduce the parent compound. The reversible redox potential $-1.8 \mathrm{~V}$ of $\mathrm{CpFe}(\mathrm{CO})_{2}\left(\mathrm{COCH}_{3}\right)$ allows the regeneration of its radical anion which drives a catalytic cycle. The lifetime of intermediates is shortened by side reactions, one of which is the migration of the acyl group from the central atom to the cyclopentadienyl ring. This explains the apparent discrepancy between products observed in preparative scale electrolysis and the absence of catalytic effects in routine voltammetric experiments.
\end{abstract}

Keywords: Carbonylation; Metal-alkyl bonds; Organoiron complexes

\section{Introduction}

The conversion of carbon monoxide to carbon chains is certainly a highly rewarding reaction. This is done usually through heterogeneous catalysis based on the FischerTropsch process. Insertion of surface-coordinated $\mathrm{CO}$ into a metal-alkyl bond is one of the supposed crucial steps of this process. The same insertion reaction has been reported to occur homogeneously within the coordination sphere of a metal centre [1-5]. A typical example is the complex ( $\mathrm{Cp}) \mathrm{Fe}(\mathrm{CO})_{2} \mathrm{CH}_{3}$ which can be transformed to a corresponding acyl derivative in a homogeneous reactor operating at high pressure of $\mathrm{CO}$ and temperature [6-8]. In spite of numerous studies of the carbonylation of $\mathrm{CpFe}$ $(\mathrm{CO})_{2} \mathrm{CH}_{3}$ and related complexes the detailed mechanism is not clear [9-12]. Alternatively, the same reaction is mediated by the activation of the metal-ligand bond by electron transfer [13]. Unlike a homogeneous reaction activated thermally, the electrochemical conversion of $\mathrm{CpFe}$ $(\mathrm{CO})_{2} \mathrm{CH}_{3}$ can be achieved at ambient temperature and atmospheric pressure, usually in the presence of a strong electron donating ligand (such as triphenyl phosphine $\mathrm{PPh}_{3}$ ) [14]:

$$
\begin{aligned}
& \mathrm{CpFe}(\mathrm{CO})_{2} \mathrm{CH}_{3}+\mathrm{PPh}_{3} \\
& \underset{\mathrm{e}^{-}}{\longrightarrow} \mathrm{CpFe}(\mathrm{CO})\left(\mathrm{PPh}_{3}\right)\left(\mathrm{CO} \cdot \mathrm{CH}_{3}\right)
\end{aligned}
$$

In the absence of an adequate ligand the acyl group formed by the bond insertion process migrates in the coordination sphere of iron leading to a substitution of the cyclopentadienyl ring [13]:

$$
\begin{aligned}
& \mathrm{CpFe}(\mathrm{CO})_{2}\left(\mathrm{CH}_{3}\right) \\
& \stackrel{\mathrm{e}^{-}}{\longrightarrow}\left(\mathrm{CpCOCH}_{3}\right) \mathrm{Fe}(\mathrm{CO})(\text { solv })^{-}+\mathrm{H}^{+} .
\end{aligned}
$$

where "solv" denotes the solvent. Electrocatalytic preparative procedures have been described; however, no catalytic effect was observed in voltammetric experiments. This suggests that the electrochemical carbonylation reaction should involve an intricate interplay of processes with different time scales which allow the electrocatalysis to proceed in a preparative time scale but prevent its observation in a voltammetric time span [13]. The present work is intended to delineate such processes and to explain the role of intermediates participating in the overall electrocatalytic reaction.

\section{. Experimental}

The compound $\mathrm{CpFe}(\mathrm{CO})_{2} \mathrm{CH}_{3}$ was synthesized according to previously published procedures (Ref. [15] and 
references therein). Triphenylphosphine (Aldrich) was of reagent grade. Tetrabutylammonium hexafluorophosphate or tetrafluoroborate used as supporting electrolytes were recrystallized and dried in vacuo. Tetrahydrofuran (THF), acetone and acetonitrile were purified by standard procedures [16]. The electrochemical measurements were made using a laboratory-built electrochemical system consisting of a fast rise time potentiostat and an interface to a personal computer $(486,33 \mathrm{MHz})$ via an $\mathrm{AD}-\mathrm{DA}$ card, PcLab model PCL818 (Advantech Co.). A three-electrode electrochemical cell was used with the $\mathrm{Ag}|\mathrm{AgCl}| 1 \mathrm{M}$ $\mathrm{LiCl}$ reference electrode separated from the test solution by a salt bridge. One type of working electrode was a valve-operated static mercury electrode, SMDE2 (Laboratorní Př́stroje, Prague). The voltage scan rate was synchronized with the formation of a fresh mercury drop electrode. The other working electrodes used in this study were gold mini- and microelectrodes with diameters $500 \mu \mathrm{m}$ and 60 $\mu \mathrm{m}$ respectively. The auxiliary electrode was a cylindrical platinum net. Oxygen was removed from the solution by passing a stream of argon. Experiments were performed at $20{ }^{\circ} \mathrm{C}$. The oxidation potential of ferrocene measured in the present arrangement was $+0.700 \mathrm{~V}$. In situ spectroelectrochemical measurements were made in a thin layer cell with a fine mesh platinum net in a three-electrode arrangement.

The cyclic staircase voltammetry was applied in its standard mode using a triangular voltage waveform and scan rates in the range from $50 \mathrm{mV} \mathrm{s}^{-1}$ to $240 \mathrm{~V} \mathrm{~s}^{-1}$. The other type of voltammetric experiment used a trapezoidal shape of imposed voltage scan. In this mode, the electrode potential was scanned to a selected value in the diffusionlimited region where the potential was held for $10 \mathrm{~s} \pm 0.5$ $\mathrm{ms}$. The reverse voltage scan was made higher with a scan rate either the same as or than the forward sweep. This "trapezoidal voltammetry" combines the advantage of the fast reverse sweep and the accumulation of products at a selected constant potential.

\section{. Results and discussion}

Experiments described in the literature conclude that the electrochemical reduction initiates a catalytic cycle (1) even keeping the electrode potential at a value where the electrolysis is just beginning to take place [14]. The present approach will investigate the electrochemical properties of the parent complex $\left(\mathrm{CpFe}(\mathrm{CO})_{2} \mathrm{CH}_{3}\right)$, the acyl derivative $\mathrm{CpFe}(\mathrm{CO})_{2}\left(\mathrm{COCH}_{3}\right)$, their interaction during the redox process and the influence of the migrating ligand $(\mathrm{CO})$ on the short-lived reaction intermediates participating in reactions (1) and (2). Emphasis will be given to the elucidation of reaction (2).

The electrochemical reduction of $\mathrm{CpFe}(\mathrm{CO})_{2} \mathrm{CH}_{3}$ proceeds as an irreversible one-electron reduction characterized by the voltammetric cathodic wave at $-2.05 \mathrm{~V}$ (Fig.

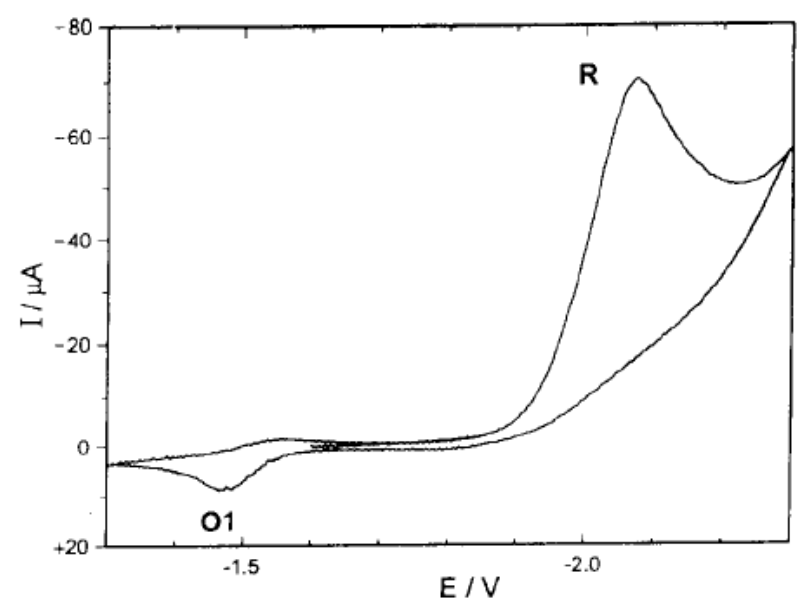

Fig. 1. The cyclic voltammogram of $3.8 \mathrm{mM} \mathrm{CpFe}(\mathrm{CO})_{2} \mathrm{CH}_{3}$ and $0.1 \mathrm{M}$ TBAPF $_{6}$ in acetone at a scan rate of $1 \mathrm{~V} \mathrm{~s}^{-1}$. The initial potential was $-1.6 \mathrm{~V}$.

1). The voltammetric pattern is not influenced by the choice of solvent, the electrode material or the presence of a phosphine ligand. Nevertheless, the IR spectrum obtained on an optically transparent electrode in the presence of $\mathrm{PPh}_{3}$ indicates that the complex loses one CO ligand (see the decrease in bands at $2005 \mathrm{~cm}^{-1}$ and $1947 \mathrm{~cm}^{-1}$ in Fig. 2 and growth of a new band at $1916 \mathrm{~cm}^{-1}$ corresponding to a single terminal $\mathrm{CO}$ group). Simultaneously a new band at $1610 \mathrm{~cm}^{-1}$ appears which is ascribed $[12,15]$ to a coordinated acyl ligand (The reduction of $\mathrm{CpFe}(\mathrm{CO})_{2} \mathrm{CH}_{3}$ by a sodium amalgam in the presence of $\mathrm{PPh}_{3}$ yields $\mathrm{CpFe}(\mathrm{CO})\left(\mathrm{PPh}_{3}\right)\left(\mathrm{COCH}_{3}\right) \quad(M=454)$, as proved by mass spectra containing the following lines: $m / e=455(\mathrm{M}+\mathrm{H}), 411\left(\mathrm{M}+\mathrm{H}-\mathrm{COCH}_{3}\right), 383(\mathrm{M}+$

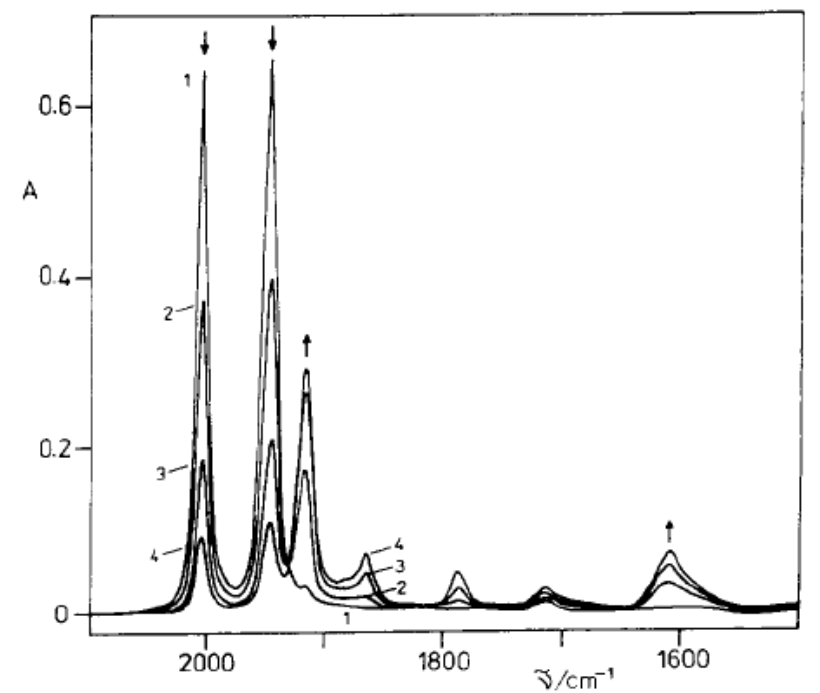

Fig. 2. The Fourier transform IR (FTIR) spectra of $1.6 \mathrm{mM} \mathrm{CpFe}(\mathrm{CO})_{2}$ $\mathrm{CH}_{3}, 5.7 \mathrm{mM} \mathrm{PPh}$ and $0.1 \mathrm{M} \mathrm{TBABF}_{4}$ in $\mathrm{THF}$ at the $\mathrm{Pt}$ minigrid electrode held at a potential of $-1.65 \mathrm{~V}$ prior to the reduction. The time interval between measurements was $0 \mathrm{~min}$ (spectrum 1), $6 \mathrm{~min}$ (spectrum 2), $12 \mathrm{~min}$ (spectrum 3 ) and $18 \mathrm{~min}$ (spectrum 4). 
$\left.\mathrm{H}-2 \mathrm{COCH}_{3}\right), 428\left(\mathrm{M}+\mathrm{NH}_{3}-\mathrm{COCH}_{3}\right)$ and $400(\mathrm{M}+$ $\mathrm{NH}_{3}-2 \mathrm{COCH}_{3}$ ).). It is sufficient to polarize the electrode on which the spectral changes are observed at a potential about $0.25 \mathrm{~V}$ more positive than the potential of the voltammetric wave, which suggests the participation of a catalytic process according to Eq. (1), triggered by the heterogeneous electron transfer.

Since the IR data confirmed the loss of one $\mathrm{Fe}-\mathrm{CO}$ bond during the reaction, we considered it important to investigate the influence of free $\mathrm{CO}$ on the dissociation equilibria involved. The catalytic nature, hidden in the almost featureless voltammetric wave in Fig. 1, can be deduced from the influence of dissolved $\mathrm{CO}$ on the magnitude of voltammetric currents, as will be shown below. The voltammetry of fresh solutions of $\mathrm{CpFe}(\mathrm{CO})_{2} \mathrm{CH}_{3}$ in the absence of $\mathrm{CO}$ exhibits an anodic oxidation wave at $-1.45 \mathrm{~V}$ (denoted by $\mathrm{O} 1$ ) that is apparently too small with respect to the reduction wave $\mathrm{R}$. However, taking into account the diffusion, one can estimate that the wave $\mathrm{O} 1$ represents the conversion of about $60 \%$ of the reduced parent complex. An experiment in which the product was accumulated is shown in Fig. 3 and confirms that the anodic wave $\mathrm{O} 1$ is due to a new reversible redox couple $\mathrm{O} 1 \mid \mathrm{R} 1$, formed in a follow-up reaction to the reduction
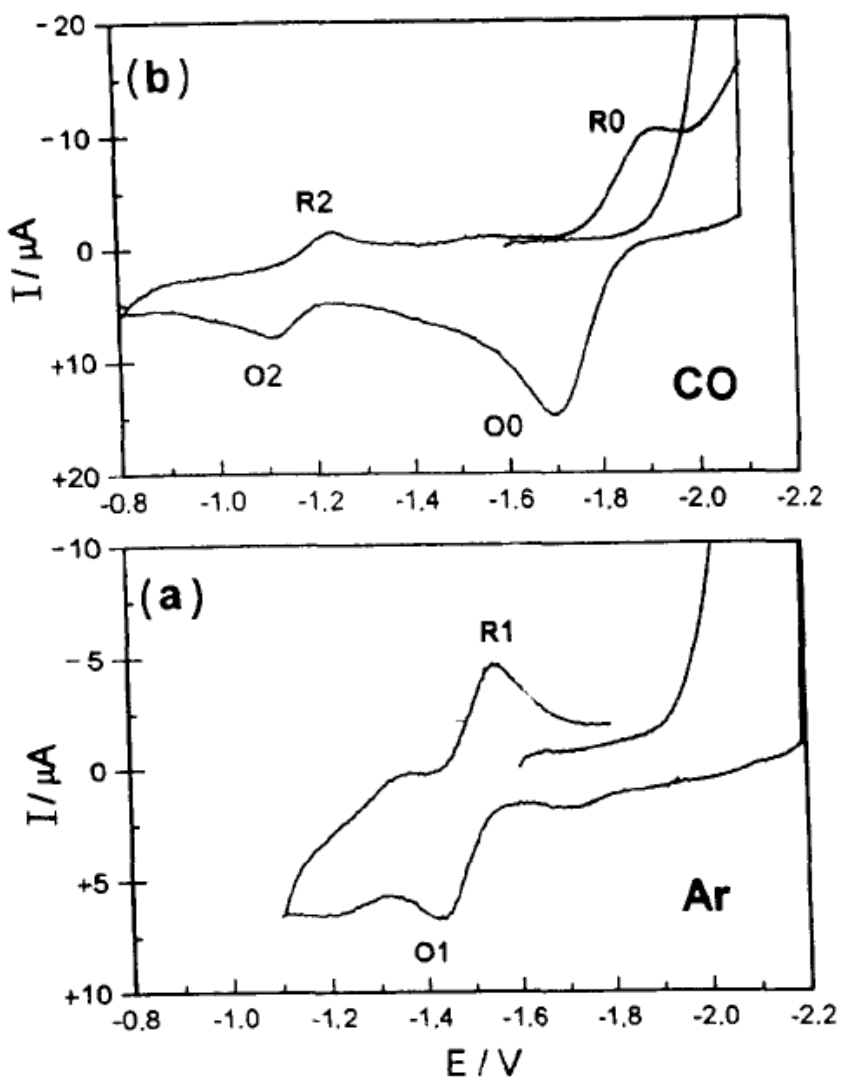

Fig. 3. The cyclic voltammetry of $3.7 \mathrm{mM} \mathrm{CpFe}(\mathrm{CO})_{2} \mathrm{CH}_{3}$ and $0.1 \mathrm{M}$ TBAPF $_{\mathrm{f}}$ in acetone with $10 \mathrm{~s}$ accumulation at the negative switching potential under atmospheres of (a) argon and (b) carbon monoxide. The scan rate was $61 \mathrm{~V} \mathrm{~s}^{-1}$. The main reduction peak is off the scalc.

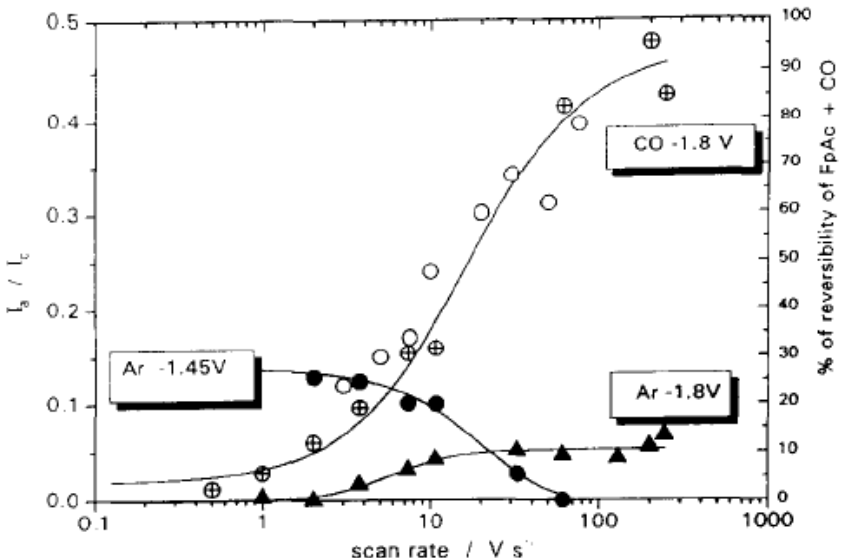

Fig. 4. The dependence of the ratio of anodic and cathodic current peaks on the scan rate. The solution was $4.2 \mathrm{mM} \mathrm{CpFe}(\mathrm{CO})_{2} \mathrm{CH}_{3}$ and $0.1 \mathrm{M}$ $\mathrm{TBAPF}_{6}$ in acetone under the atmosphere of argon $(\mathbf{\Lambda})$ or under the atmosphere of $\mathrm{CO}(\oplus)$. The curves are labelled with the corresponding peak potentials of the waves $\mathrm{OO}$ and OI. O. data obtained for the independent reduction of an authentic sample of $\mathrm{CpFe}\left(\mathrm{CO}_{2}\left(\mathrm{COCH}_{3}\right)\right.$ under the atmosphere of $\mathrm{CO}$ (see the text).

process $R$. When a similar experiment is performed in solution saturated with dissolved $\mathrm{CO}$ (Fig. 3(b)), another reversible system $\mathrm{O} 0 \mid \mathrm{R} 0$ (at $-1.8 \mathrm{~V}$ ) is generated (a small anodic wave identical to $\mathrm{O} 0$ can also be observed under inert atmosphere but only at very fast scan rate (see data in Fig. 4)), instead of the formation of the reversible redox couple O1|R1 (observed only under argon). The redox potential of the $\mathrm{O} 0 \mid \mathrm{R} 0$ couple is identical with the reversible potential of the compound $\mathrm{CpFe}(\mathrm{CO})_{2}\left(\mathrm{COCH}_{3}\right)$. The lifetime of both redox pairs generated by an EC process can be estimated from voltammetric currents measured at various scan rates (Fig. 4). Our data show unambiguously that the formation of $\mathrm{CpFe}(\mathrm{CO})_{2}\left(\mathrm{COCH}_{3}\right)$ can be traced only as an intermediate by using fast scan voltammetry and that the yield is considerably enhanced by the presence of free $\mathrm{CO}$. This finding seems to contradict the previously established experience that a long-term electrolysis yields the acyl compound, while its formation cannot be seen in the voltammetric time scale. Evidently, the mechanism of the electrochemical $\mathrm{CO}$ insertion reaction is a complicated process involving several other intermediates whose detection is difficult in routine experiments.

The observation of $\mathrm{CpFe}(\mathrm{CO})_{2}\left(\mathrm{COCH}_{3}\right)^{-\cdot}$ (wave $\mathrm{O} 0$ in Fig. 3(b)) only at short time scales (Fig. 4) was unexpected. Indeed, the redox couple of waves Ro|O0 (at $-1.80 \mathrm{~V}$, Fig. 5(a)) is almost perfectly chemically reversible even at long time scales. So it is a puzzling effect that $\mathrm{CpFe}(\mathrm{CO})_{2}\left(\mathrm{COCH}_{3}\right)^{-\cdot}$ could be formed in the initial stages of the reaction, that is at short time scales (Fig. $5(\mathrm{a})$ ), but vanishes at a longer time scale. This evidence suggests the following: $\mathrm{CpFe}(\mathrm{CO})_{2}\left(\mathrm{COCH}_{3}\right)^{-\cdot}$ is stable under conditions where it is produced alone; however, it becomes unstable at long time scales when it encounters 

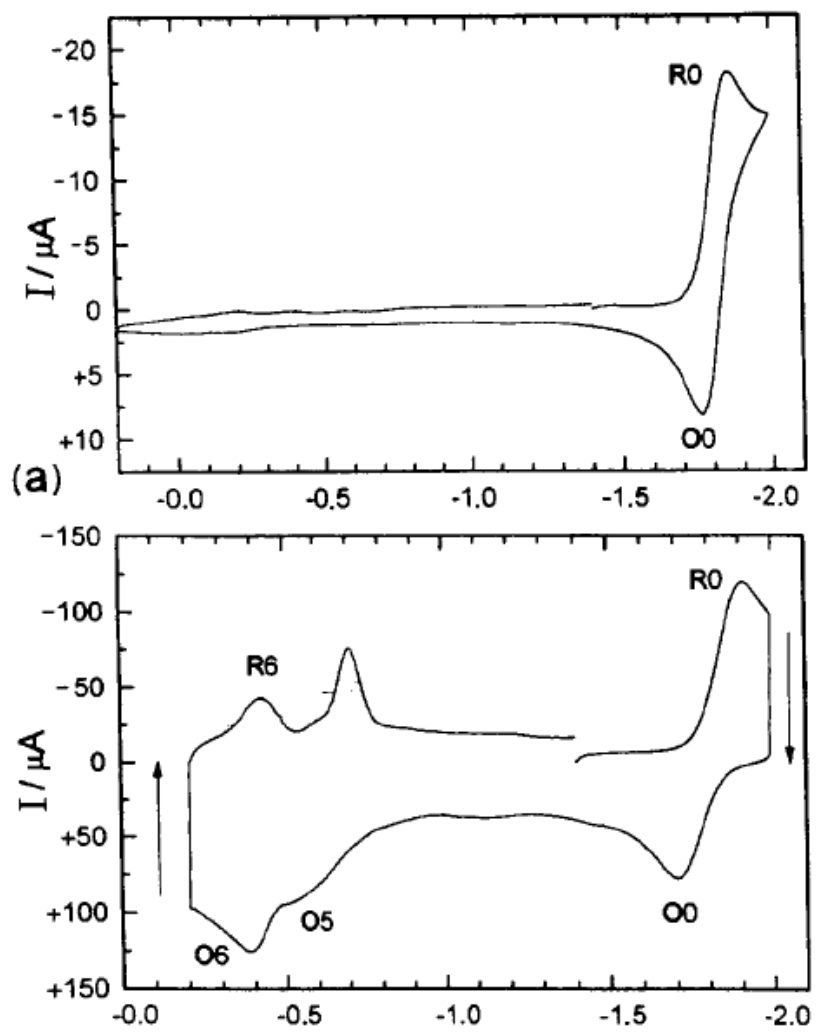

(b)

$E / V$

Fig. 5. The cyclic voltammetry of $0.8 \mathrm{mM}(\mathrm{Cp}) \mathrm{Fe}(\mathrm{CO}),\left(\mathrm{COCH}_{3}\right)$ and 0.1 $M$ TBAPF $_{6}$ acetone. (a) Measured using the triangular waveform with sweep rate $1 \mathrm{~V} \mathrm{~s}^{-1}$ and the initial potential $-1.4 \mathrm{~V}$. (b) Measured at the scan rate $61 \mathrm{~V} \mathrm{~s}^{-1}$ and using two accumulation periods, each of $10 \mathrm{~s}$ duration, at potentials of $-2.0 \mathrm{~V}$ (formation of reduction products) and $-0.2 \mathrm{~V}$ (reoxidation of products).

the presence of reactants, products or intermediates generated from $\mathrm{CpFe}(\mathrm{CO})_{2} \mathrm{CH}_{3}$ and $\mathrm{CO}$.

A first tentative explanation can be based on the existence of a homogeneous electron transfer from $\mathrm{CpFe}$ $(\mathrm{CO})_{2}\left(\mathrm{COCH}_{3}\right)^{-\cdot}$ to unreacted $\mathrm{CpFe}(\mathrm{CO})_{2} \mathrm{CH}_{3}$. Such a reaction could have a key role in the overall performance of the catalytic $\mathrm{CO}$ insertion [2-4]. The experimental test of the above hypothesis was done by investigation of the reduction current and the reversibility of $\mathrm{CpFe}(\mathrm{CO})_{2}-$ $\left(\mathrm{COCH}_{3}\right)$ in the presence of varied concentrations of $\mathrm{CpFe}(\mathrm{CO})_{2} \mathrm{CH}_{3}$. A typical result is shown in Fig. 6, where a substantial increase in the wave of $\mathrm{CpFe}(\mathrm{CO})_{2}\left(\mathrm{COCH}_{3}\right)$ is concomitant with a loss of its reversibility. At high scan rate the homogeneous catalytic reduction is suppressed by a fast reoxidation of the radical anion during the reverse scan before the electron transfer to $\mathrm{CpFe}(\mathrm{CO})_{2} \mathrm{CH}_{3}$ could occur: the voltammetric pattern corresponds then to the sum of currents of both components and the reversible pair of redox waves of $\mathrm{CpFe}(\mathrm{CO})_{2}\left(\mathrm{COCH}_{3}\right)$ reappears. The experimental conditions for data in Fig. 6 (the mixture of $\mathrm{CpFe}(\mathrm{CO})_{2}\left(\mathrm{COCH}_{3}\right)$ and $\left.\mathrm{CpFe}(\mathrm{CO})_{2} \mathrm{CH}_{3}\right)$ cannot mimic fully the true situation corresponding to generation of such a mixture in situ (Fig. 4). Nevertheless, it appears that the

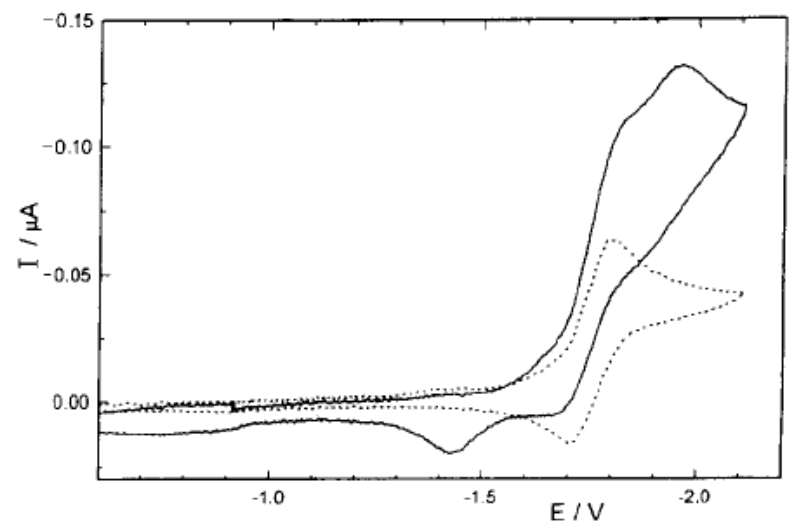

Fig. 6. The cyclic voltammetry of $1 \mathrm{mM}(\mathrm{Cp}) \mathrm{Fe}(\mathrm{CO})_{2}\left(\mathrm{COCH}_{3}\right)$ and 0.1 $\mathrm{M} \mathrm{TBAPF}_{6}$ in THF (- - ) and in the presence of two equivalents of $\mathrm{CpFe}(\mathrm{CO})_{2} \mathrm{CH}_{3}$ (-). The scan rate was $0.1 \mathrm{~V} \mathrm{~s}^{-1}$.

electron transfer between $\mathrm{CpFe}(\mathrm{CO})_{2}\left(\mathrm{COCH}_{3}\right)^{-\cdot}$ and $\mathrm{CpFe}(\mathrm{CO})_{2} \mathrm{CH}_{3}$ is too slow to account for the decay of $\mathrm{CpFe}(\mathrm{CO})_{2}\left(\mathrm{COCH}_{3}\right)^{-\cdot}$ in the range of a few tens of volts per second, as observed in Fig. 4. The value of the rate constant $k_{\text {et }}$ of the homogeneous electron transfer reaction was estimated to be $3200 \mathrm{M}^{-1} \mathrm{~s}^{-1}$. The observed decay has to include yet another reaction.

The problem of the acyl transfer reaction (2) [13] imposes the question of at which stage the metal-bound acyl migrates to the $\mathrm{Cp}$ ring. One can prove the existence of such a process by in situ FTIR spectroscopy (Fig. 7). The solution of $\mathrm{CpFe}(\mathrm{CO})_{2} \mathrm{CH}_{3}$ yields two absorption bands of $\mathrm{CO}$ vibrations at $2005 \mathrm{~cm}^{-1}$ and $1947 \mathrm{~cm}^{-1}$. By scanning the electrode potential slowly, a gradual decrease in these bands is observed and two new, less intense bands at $1866 \mathrm{~cm}^{-1}$ and $1788 \mathrm{~cm}^{-1}$ appear. The new bands correspond to two CO ligands in the reduced complex. In addition to these bands of coordinated $\mathrm{CO}$ group, two new

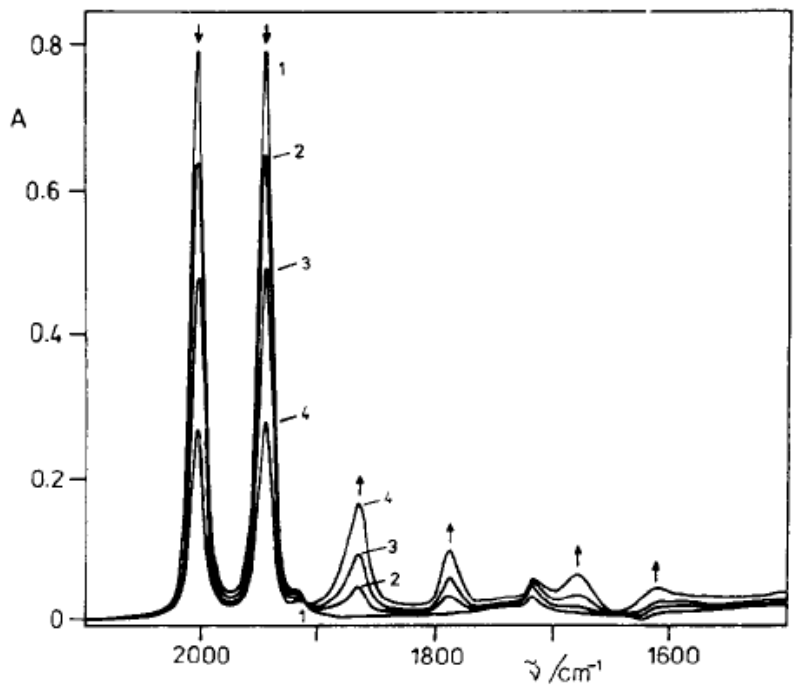

Fig. 7. The FTIR spectra of $2.8 \mathrm{mM} \mathrm{CpFe}(\mathrm{CO})_{2} \mathrm{CH}_{3}$ and $0.1 \mathrm{M} \mathrm{TBABF}_{4}$ in THF at different potentials of the Pt minigrid electrode: spectrum 1, 0 $\mathrm{V}$; spectrum 2, $-1.85 \mathrm{~V}$; spectrum 3,-1.95 V; spectrum 4, $-2.0 \mathrm{~V}$. The time interval between measurements was $150 \mathrm{~s}$. 
bands associated with the migration of $\mathrm{CO}$ ligand can be seen. The band at $1679 \mathrm{~cm}^{-1}$ was ascribed in the literature to the vibration of a $\mathrm{CO}$ group attached to the cyclopentadienyl ring $[17,18]$. The slightly less intense band at 1610 $\mathrm{cm}^{-1}$ corresponds to the vibration of acyl group $-\mathrm{COCH}_{3}$ coordinated to iron. The $\mathrm{CO}$ vibration of the acyl ligand is characterized by much lower wavenumbers than expected for a keto group owing to interaction with d orbitals of the metal. Two limiting forms of $\mathrm{CO}$ have the double bond either between carbon and oxygen or between carbon and metal resulting in an average configuration characterized by lower vibration frequency compared with organic aldehydes or ketones [12].

The process of acyl migration from the iron atom to $\mathrm{Cp}$ ligand requires one to reconsider the stability of the $\mathrm{CpFe}$ $(\mathrm{CO})_{2}\left(\mathrm{COCH}_{3}\right)$ complex in the reduced state. A meticulous inspection of the voltammogram of $\mathrm{CpFe}(\mathrm{CO})_{2}$ $\left(\mathrm{COCH}_{3}\right)$ reveals a certain possibility of formation of products reoxidized at about $-0.4 \mathrm{~V}$. Because of a large voltage span between the wave of $\mathrm{CpFe}(\mathrm{CO})_{2}$ $\left(\mathrm{COCH}_{3}\right)$ and that of additional products, diffusion renders the detection of possible products rather difficult. This obstacle was resolved by application of "trapezoidal", voltammetry (i.e. holding the potential scan for the sake of accumulation of products at a suitable potential). Fig. 5(b) proves that the reduction of $\mathrm{CpFe}(\mathrm{CO})_{2}\left(\mathrm{COCH}_{3}\right)$ is an EC process generating two intermediates with reoxidation potentials of approximately -0.5 and $-0.4 \mathrm{~V}$. The appearance of a reversible redox couple at $-0.4 \mathrm{~V}$ correlates well with the reoxidation waves observed in solutions of $\mathrm{CpFe}(\mathrm{CO})_{2} \mathrm{CH}_{3}$ subjected to a non-exhaustive electrolysis (Fig. 8). The partially electrolysed solution exhibits a wave at $-0.32 \mathrm{~V}$, ascribed [9] to $\left(\mathrm{CH}_{3} \mathrm{COCp}\right) \mathrm{Fe}(\mathrm{CO})_{2}$ anion. Another small wave is observed at $-0.1 \mathrm{~V}$ that may correspond to free substituted CpAcyl ligand in the form of an anion. Acylcyclopentadienide anion is very difficult to prepare; however, its electrochemical in situ generation

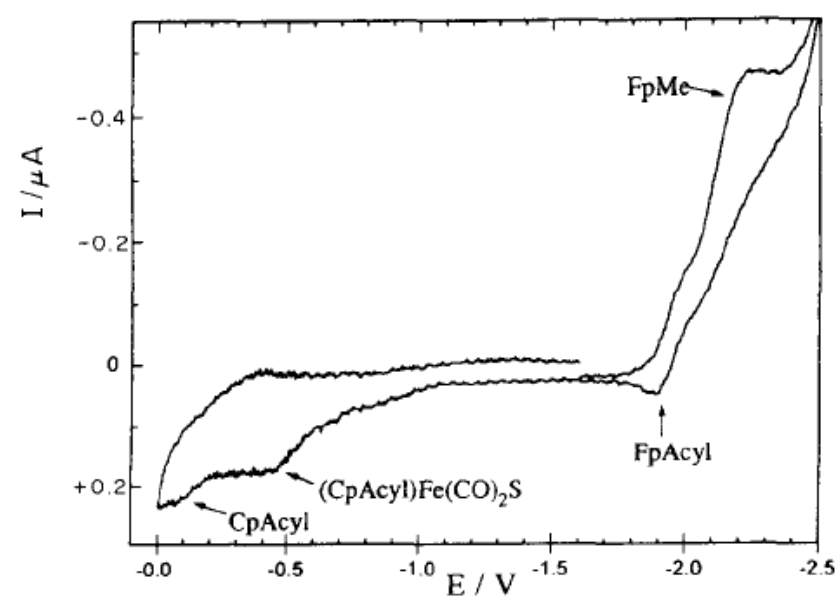

Fig. 8 . The cyclic voltammetry of partially $(40 \%)$ electrolysed solution of initial concentration $4 \mathrm{mM} \mathrm{CpFe}(\mathrm{CO})_{2} \mathrm{CH}_{3}+0.1 \mathrm{M} \mathrm{TBABF}_{4}$ in acetone at $\mathrm{Au}$ microelectrode at $1 \mathrm{~V} \mathrm{~s}^{-1}$. was successful [10]. Its anodic oxidation potential was reported to be identical with that of the wave at $-0.1 \mathrm{~V}$ found here. Considering the FTIR data described above, it can be concluded that the acyl-substituted $\mathrm{Cp}$ ligand partially dissociates during the electrolysis.

At this stage it appears that $\mathrm{CpFe}(\mathrm{CO})_{2}\left(\mathrm{COCH}_{3}\right)^{-\cdot}$ is intrinsically unstable when it is subjected to the reaction conditions that resemble its formation from $\mathrm{CpFe}(\mathrm{CO})_{2} \mathrm{CH}_{3}$ and $\mathrm{CO}$. Under the conditions of Fig. 5(a), this intrinsic instability is suppressed because the concentration of the intermediates in the diffusion layer is small. However, when more products are accumulated, as in Fig. 5(b), this instability is revealed by the large height of the waves 05 and 06. Since we know (i) that the ultimate products correspond to a migration of the acyl group to the $\mathrm{Cp}$ ring (see the IR spectra above and the voltammetry of partially electrolysed solution in Fig. 8) and (ii) that $\mathrm{CO}$ is released during the reduction of $\mathrm{CpFe}(\mathrm{CO})_{2} \mathrm{CH}_{3}$ (see IR and Fig. 2 ), one can suppose that the migration of the acyl group is enhanced in the presence of $\mathrm{CO}$. Thus $\mathrm{CpFe}(\mathrm{CO})_{2}-$ $\left(\mathrm{COCH}_{3}\right)^{-}$would be stable when it is produced alone because no $\mathrm{CO}$ ligand is available to promote the migration of acyl group to the $\mathrm{Cp}$ ring. However, it becomes unstable when such a ligand is present. This mechanistic assumption was tested in the following experiment. The reversible voltammetry of $\mathrm{CpFe}(\mathrm{CO})_{2}\left(\mathrm{COCH}_{3}\right)$ was scrutinized under the atmosphere of $\mathrm{CO}$. The presence of an excess of the $\mathrm{CO}$ ligand causes a very efficient consumption of $\mathrm{CpFe}(\mathrm{CO})_{2}\left(\mathrm{COCH}_{3}\right)^{-\cdot}$ via a follow-up chemical reaction leading to a voltammetric irreversibility at lower scan rates. At high scan rates this chemical process is suppressed and the reversibility of voltammetric wave is restored. The corresponding data are shown in Fig. 4 (open circles). It is noteworthy that these data coincide with those relative to $\mathrm{CpFe}(\mathrm{CO})_{2}\left(\mathrm{COCH}_{3}\right)^{-\cdot}$ generated during the reduction of $\mathrm{CpFe}(\mathrm{CO})_{2} \mathrm{CH}_{3}$ (cross-centred circles). One can then safely conclude that in both cases the same kinetics are involved. This reaction plays a key role in the overall reaction scheme (discussed in the last section) because it identifies the main termination reaction of the catalytic cycle. The CO-promoted migration mechanism is characterized by the pseudo-first-order homogeneous rate constant $k_{\mathrm{co}}[\mathrm{CO}]$ which was estimated to be $50 \mathrm{~s}^{-1}$.

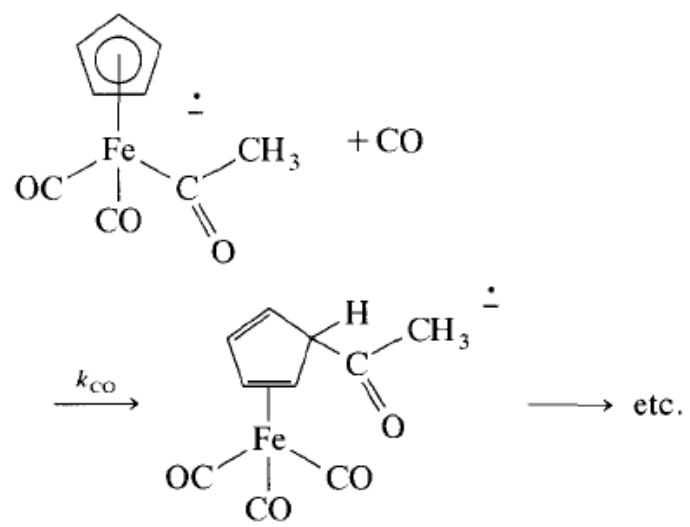


<smiles>CC(=O)C(C=O)(C=O)c1ccccc1</smiles><smiles>CCCC(=O)C1(C(=O)[O-])CC=CC1C(C)=O</smiles>

This also logically explains why the stability of $\mathrm{CpFe}$ $(\mathrm{CO})_{2}\left(\mathrm{COCH}_{3}\right)^{-\cdot}$ is about 10 times higher when it is generated by the reduction of $\mathrm{CpFe}(\mathrm{CO})_{2} \mathrm{CH}_{3}$ under the argon atmosphere than under the atmosphere of $\mathrm{CO}$ (compare in Fig. 4 the data marked by full triangles and crossed circles). The simultaneous existence of reactions (3) and (4) may explain all the above observations. When the reduction of $\mathrm{CpFe}(\mathrm{CO})_{2}\left(\mathrm{COCH}_{3}\right)$ alone is performed (Fig. 5) only the relatively slow reaction (4) would play a role leading to the observation of an almost chemically reversible voltammetry. When $\mathrm{CpFe}(\mathrm{CO})_{2}\left(\mathrm{COCH}_{3}\right)^{-\cdot}$ is produced by reduction of $\mathrm{CpFe}(\mathrm{CO})_{2} \mathrm{CH}_{3}$ under an argon atmosphere, a small steady state concentration of $\mathrm{CO}$ is present in the diffusion layer that is supplied by the fragmentation of the 19-electron $\mathrm{CpFe}(\mathrm{CO})_{2} \mathrm{CH}_{3}^{-\cdot}$ (Fig. 4, data marked by full triangles). In this respect it must be noted that the increase in the wave O1 (Fig. 4, full circles) is concomitant with the decrease in the wave $\mathrm{O} 0(\mathrm{CpFe}-$ $(\mathrm{CO})_{2}\left(\mathrm{COCH}_{3}\right)^{-}$, full triangles in Fig. 4):<smiles>CC(=O)c1ccccc1C(C)(C)C(=O)[O-]</smiles><smiles>CC(=O)C(=O)C1C(C(C)=O)C=CC1C(C)=O</smiles>

When the reduction of $\mathrm{CpFe}(\mathrm{CO})_{2} \mathrm{CH}_{3}$ is performed under an excess of $\mathrm{CO}$, reaction (3) is even more dominant because the concentration of $\mathrm{CO}$ in the diffusion layer is much larger. As a result the decay of $\mathrm{CpFe}(\mathrm{CO})_{2}-$ $\left(\mathrm{COCH}_{3}\right)^{-\cdot}$ occurs at higher scan rates.

\section{Reaction mechanism}

On the basis of experimental observations described above, the competitive and catalytic reactions participating in the overall electrochemical activation of $\mathrm{CpFe}(\mathrm{CO})_{2} \mathrm{CH}_{3}$ can be described by Scheme 1. The potentials in Scheme 1 are assigned tentatively with respect to the experimental conditions used in this study). The electrochemical oneelectron reduction of $\mathrm{CpFe}(\mathrm{CO})_{2} \mathrm{CH}_{3}$ yields a highly unstable form $\mathrm{CpFe}(\mathrm{CO})_{2} \mathrm{CH}_{3}^{-\cdot}$ that chemically decomposes by at least three reaction pathways. The principal reactions are the loss of $\mathrm{CO}$ ligand and the insertion of $\mathrm{CO}$ into the metal-methyl bond. The first reaction leads to $\mathrm{CpFe}(\mathrm{CO})$ (solv) $\mathrm{Me}^{-\cdot}$ (where solv is the solvent) giving the reoxidation wave at $-1.45 \mathrm{~V}$. The second reaction yields $\mathrm{CpFe}$ $(\mathrm{CO})($ solv $)\left(\mathrm{COCH}_{3}\right)^{-\cdot}$ which can be stabilized by trapping $\mathrm{CO}$ released in the first reaction path or supplied by the atmosphere of $\mathrm{CO}$ ligand or by added phosphine. (The reoxidation of $\mathrm{CpFe}(\mathrm{CO})($ solv $)\left(\mathrm{COCH}_{3}\right)^{-}$probably proceeds in a wave $\mathrm{O} 2$ at $-1.2 \mathrm{~V}$. O2 has a transient character and is enhanced by the presence of CO (e.g. under the conditions when the first pathway is suppressed). $\mathrm{O} 2$ can also be observed in high resolution voltammograms as a product of a direct reduction of $\mathrm{CpFe}(\mathrm{CO})_{2}$ $\left(\mathrm{COCH}_{3}\right)$ in the absence of $\mathrm{CpFe}(\mathrm{CO})_{2} \mathrm{CH}_{3}$.) If a strong electron donating phosphine ligand is present the main product of the large-scale electrolysis is $\mathrm{CpFe}(\mathrm{CO})\left(\mathrm{PR}_{3}\right)$ $\left(\mathrm{COCH}_{3}\right)$, as described in the literature [19]. Without an external supply of $\mathrm{CO}$ the stabilization is not very efficient, owing to the small steady state concentration of $\mathrm{CO}$. Once the acyl derivative is formed, it is capable of reducing $\mathrm{CpFe}(\mathrm{CO})_{2} \mathrm{CH}_{3}$ in a homogeneous reaction and in this way triggering the electrocatalytic cycle.

By analogy the with properties of the unstable $\mathrm{CpFe}$ $(\mathrm{CO})_{2} \mathrm{CH}_{3}-\cdot$ radical anion, the 19-electron intermediates $\mathrm{CpFe}(\mathrm{CO})_{2}\left(\mathrm{COCH}_{3}\right)^{-\cdot}$ and $\mathrm{CpFe}(\mathrm{CO})($ solv $)\left(\mathrm{COCH}_{3}\right)^{-}$ are expected to have a similar instability, causing the slippage of the $\mathrm{Cp}$ ring to $\eta^{4}$ configuration and the migration of the acyl group. The change in the coordination of the $\mathrm{Cp}$ ligand is a prerequisite to the migration of the acyl group to the Cp ring (observed here in IR spectra). Similar migration of a group from the central transition metal atom to the $\mathrm{Cp}$ ring is well established in several other organometallic reactions [20-23]. A very similar process of the migration of acyl group was found during an attempted acylation of $\left(\eta^{5}\right.$-cycloheptadienyl)$\mathrm{Fe}(\mathrm{CO})_{2} \mathrm{CH}_{3}$ complex.

The reactivity of the anion radical $\mathrm{CpFe}(\mathrm{CO})_{2}-$ $\left(\mathrm{COCH}_{3}\right)^{-\cdot}$ plays a crucial role (as important as the reactivity of $\mathrm{CpFe}(\mathrm{CO})_{2} \mathrm{CH}_{3}^{-\cdot}$ ) in the propagation of the catalytic cycle. Moreover, it explains the discrepancy between the products obtained in preparative electrolysis (i.e. catalysis $)$ and in voltammetry. $\mathrm{CpFe}(\mathrm{CO})_{2}\left(\mathrm{COCH}_{3}\right)^{-\cdot}$ participates in two main reactions: (i) the redox exchange with $\mathrm{CpFe}(\mathrm{CO})_{2} \mathrm{CH}_{3}$ (e.g. the propagation) and (ii) the 


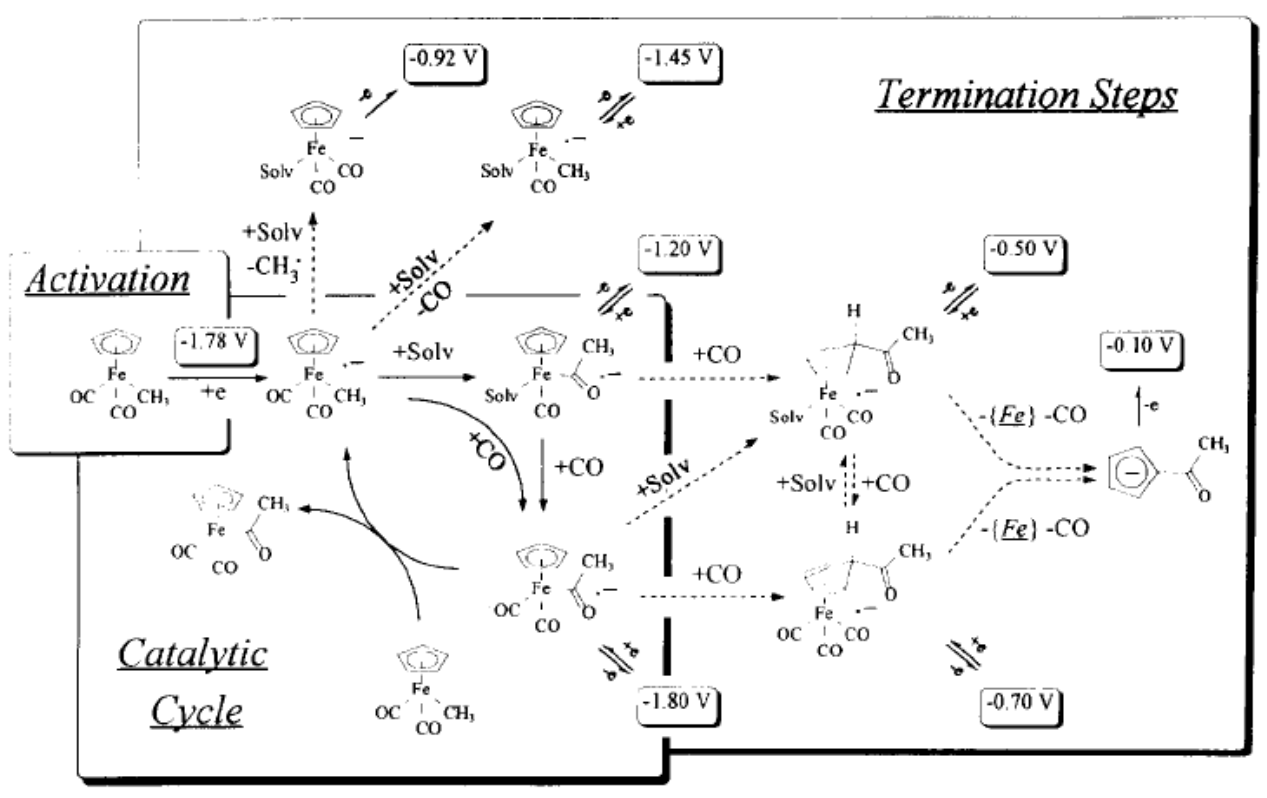

Scheme 1.

migration of the acyl group promoted by $\mathrm{CO}$ (e.g. termination steps), which are shown in a simplified Scheme 2. Data in Fig. 4 indicate that the CO-assisted formation of $\mathrm{CpFe}(\mathrm{CO})_{2}\left(\mathrm{COCH}_{3}\right)$ is time independent above $200 \mathrm{~V}$ $\mathrm{s}^{-1}$, affording an estimate of the lower limit of the pseudo-first-order rate constant for the $\mathrm{CO}$ insertion-addition reaction to values $k[\mathrm{CO}]>5000 \mathrm{~s}^{-1}$. The estimated values of $k_{\mathrm{et}}=3200 \mathrm{M}^{-1} \mathrm{~s}^{-1}$ and $k_{\mathrm{co}}[\mathrm{CO}]=50 \mathrm{~s}^{-1}$ allow us to calculate the maximal conversion efficiency of each catalytic cycle by

$p_{\max }=\frac{k_{\mathrm{et}}[\mathrm{FpMe}]}{k_{\mathrm{et}}[\mathrm{FpMe}]+k_{\mathrm{co}}[\mathrm{CO}]}=\frac{1}{1+15.6 /[\mathrm{FpMe}]}$

where $\left[\mathrm{CpFe}(\mathrm{CO})_{2} \mathrm{CH}_{3}\right]$ is in millimolar units. A typical electropreparation may use $\left[\mathrm{CpFe}(\mathrm{CO})_{2} \mathrm{CH}_{3}\right]=100 \mathrm{mM}$ that allows us to achieve $86 \%$ efficiency for each cycle, while a voltammetric experiment using $\left[\mathrm{CpFe}(\mathrm{CO})_{2}\right.$ $\left.\mathrm{CH}_{3}\right]=1 \mathrm{mM}$ is performed only at $6 \%$ efficiency and therefore the catalytic effects cannot be routinely observed. These numbers are maximum values for each cycle since we have identified other termination processes (see Scheme

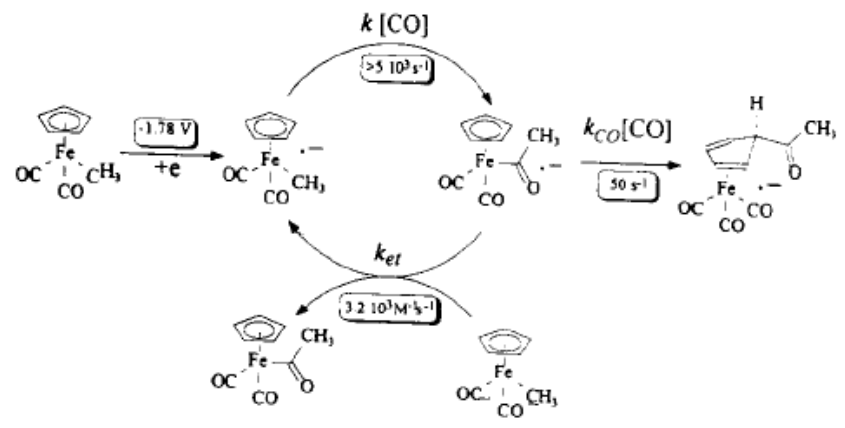

Scheme 2 .
1). Among these, several, not fully identified in the present study, produce additional small anodic waves located between -0.6 and $-1.0 \mathrm{~V}$ : $03(-0.92 \mathrm{~V})$ and $\mathrm{O} 4(-0.70$ V) which may further lower the real efficiency of the whole process.

\section{Acknowledgement}

This work was performed as a part of the project COST D5/008/94 supported by the Ministry of International Affairs, Paris, the Ministry of Education, Prague and CNRS, Paris. The authors thank Dr. J. Čejka for performing the gas chromatography-mass spectroscopy analysis.

\section{References}

[1] R.H. Marguson, R. Meirowitz, S. Zulu and W.P. Giering, Organometallics, 2 (1983) 460.

[2] J.P. Colleman, Acc. Chem. Res., 8 (1975) 342.

[3] M.P. Cooke, Jr., J. Am. Chem. Soc., 92 (1970) 6080.

[4] C.P. Casey, R.A. Widenhoefen and J.M. O'Connor, J. Organomet. Chem., 428 (1992) 99.

[5] M.J. Wax and R.G. Bergman, J. Am. Chem. Soc., 103 (1981) 7028.

[6] T.C. Forschner and A.R. Cutler, Organometallics, 4 (1985) 1247.

[7] R.B. King, A.D. King, Jr., M.Z. Igbal and C.C. Frazier, J. Am. Chem. Soc., 100 (1978) 1687.

[8] R.S. Su and A. Wojciki, J. Organomet. Chem., 87 (1971) 231.

[9] M. Green and D.J. Westlake, J. Chem. Soc. A, (1971) 367.

[10] I.S. Butler, F. Basolo and R.G. Pearson, Inorg. Chem., 6 (1967) 2074.

[11] A.J. Hart-Davis and R.J. Mawby, J. Chem. Soc. A, (1969) 2403.

[12] R.B. King, J. Am. Chem. Soc., 85 (1963) 1919.

[13] D. Miholová and A.A. Vlček, Proc. 10th, Conf. on Coordination Chemistry 1985 , p. 275.

[14] D. Miholová and A.A. Vlček, J. Organometal. Chem. 240 (1982) 413. 
[15] R.B. King, in J.J. Eisch and R.B. King (eds.), Organometallic Synthesis, Vol. 1, Academic Press, New York, 1965, p. 175.

[16] J.A. Riddick and W.B. Bunger, Organic Solvents, Wiley Interscience, New York, 1970, p. 572.

[17] N. El Murr and A. Chaloyard, J. Organomet. Chem., 193 (1980) C60.

[18] A. Chaloyard and N. El Murr, Inorg. Chem., 19 (1980) 3217.

[19] D. Miholová and A.A. Vlček, Inorg. Chim. Acta, 43 (1080) 43.

[20] S.R. Beryhill and B. Sharenow, J. Organomet. Chem., 221 (1981) 143.
[21] S.R. Beryhill, G.L. Clevenger and F.Y. Burdurlu, Organometallics, 4 (1985) 1509.

[22] G. Fachinetti, S.D. Nero and C. Floriani, J. Chem. Soc., Dalton Trans., (1976) 203.

[23] F.W.S. Benfield and L.M.H. Green, J. Chem. Soc., Dalton Trans., (1974) 1324

[24] M.W. Gregory, R.A. Fisher and R.A. Heyn, Organometallics, 5 (1986) 818. 